\title{
Gesture Anak Autis dalam Menyelesaikan Soal Matematika Materi Penjumlahan Bilangan Bulat
}

\author{
Rizky Nova Damayanti ${ }^{1}$, Subanji $^{2}$, Cholis Sa'dijah ${ }^{2}$ \\ ${ }^{1}$ Pendidikan Dasar-Universitas Negeri Malang \\ ${ }^{2}$ Pendidikan Matematika-Universitas Negeri Malang
}

\begin{tabular}{l}
\hline INFO ARTIKEL \\
\hline Riwayat Artikel: \\
Diterima: 29-01-2019 \\
Disetujui: 10-09-2019 \\
\hline
\end{tabular}

\section{Kata kunci:}

autistic children; gesture;

math question;

anak autis:

gesture;

soal matematika

\begin{abstract}
ABSTRAK
Abstract: Children with autism spectrum disorders or ASD are one of the developmental disorders of the nerves that are characterized by social and communication definitions. Developmental abnormalities in the nerve will affect brain development and child communication. Therefore, when children communicate, a gesture will emerge as a sign the child is communicating to convey the message. Based on this, researchers will conduct research on child gestures that arise in solving math problems. Gesture that appears will be recorded using a camera so that it will be known what gesture appears in the child. The study was conducted on two moderate autistic children with different levels but the same material. This study resulted in the gesture of an autistic child appearing in solving a mathematical problem as a gesture of conformity and incompatibility. Where the suitability of the corresponding gesture shown by the child is like pointing and counting. Whereas for gesture mismatch shows the child turns to another object, calculates with different hand gestures and points but not to solve the problem.
\end{abstract}

\begin{abstract}
Abstrak: Anak dengan gangguan spektrum autisme atau ASD adalah salah satu kelainan perkembangan pada saraf yang ditandai oleh definisi sosial dan komunikasi. Kelainan perkembangan pada saraf tersebut akan memengaruhi perkembangan otak dan komunikasi anak. Oleh karena itu, ketika anak berkomunikasi, maka akan muncullah gesture sebagai tanda anak berkomunikasi untuk menyampaikan pesan. Berdasarkan hal tersebut peneliti akan melakukan penelitian tentang gesture anak yang muncul dalam menyelesaikan soal matematika. Gesture yang muncul akan direkam menggunakan kamera sehingga akan diketahui gesture apa yang muncul pada anak. Penelitian dilakukan pada dua anak autis sedang dengan jenjang tingkatan yang berbeda tetapi materi yang sama. Penelitian ini menghasilkan bahwa gesture anak autis yang muncul dalam menyelesaikan soal matematika merupakan gesture kesesuaian dan ketidaksesuaian. Dimana kesesuaian berisi gesture yang sesuai ditunjukkan anak, seperti menunjuk dan menghitung. Sementara itu, untuk ketidaksesuaian gesture menunjukkan anak menoleh ke objek lain, menghitung dengan gesture tangan yang berbeda dan menunjuk, tetapi bukan untuk menyelesaikan soal.
\end{abstract}

\author{
Alamat Korespondensi: \\ Rizky Nova Damayanti \\ Pendidikan Dasar \\ Universitas Negeri Malang \\ Jalan Semarang 5 Malang \\ E-mail: rizkynova.damayanti@gmail.com
}

Anak autis merupakan anak yang memiliki kebutuhan secara khusus dengan gangguan spektrum autisme yang biasa disebut Autisme Spectrum Disorder (ASD). Anak dengan gangguan spektrum autisme dapat terjadi karena bermacam-macam faktor seperti faktor keturunan atau genetik. Hal tersebut selaras dengan pernyataan yang disampaikan oleh (Hallmayer et al., 1996; Swillen, Hellemans, Steyaert, \& Fryns, 1996; Szatmari et al., 1996) bahwa terdapat hubungan positif bahwa kelainan genetik dapat menjadi salah satu faktor yang dapat menyebabkan beberapa kasus autisme. Kelainan genetik tersebut dapat berupa sindrom $\mathrm{X}$ yang dinyatakan tidak kuat atau rapuh sehingga terjadi kasus autisme pada beberapa keluarga. Anak dengan gangguan spektrum autisme atau ASD merupakan anak yang mempunyai kelainan pada saraf. Sama halnya seperti yang dikemukakan oleh (Iuculano et al., 2014) bahwa gangguan spektrum autisme atau ASD adalah salah satu kelainan perkembangan pada saraf yang ditandai oleh definisi sosial dan komunikasi. Kelainan perkembangan pada saraf tersebut akan memengaruhi perkembangan otak pada ASD. Sedangkan menurut (Mundy \& Markus, 1997) gangguan sosial dan komunikasi pada anak autis ditandai oleh kekuatan dan kelemahan sindrom secara spesifik dan bukan melihat ada tidaknya respon yang lebih terhadap orang lain. Berdasarkan penjelasan tersebut, dapat diketahui bahwa karakteristik ASD ialah anak yang memiliki gangguan perkembangan komunikasi dan sosial serta kurang fleksibilitasnya dalam berpikir. 
Adapun menurut (Mustafa, Nusantara, Subanji, \& Irawati, 2016) yang menunjukkan bahwa ketiga karakteristik itu saling berkoneksi, semisal jika satu karakteristik (berpikir) yang dimiliki anak mengalami masalah, maka dapat memengaruhi kedua karakteristik lainnya (komunikasi dan sosial). Anak autis (ASD) digolongkan menjadi beberapa tipe kognitif atau cara berpikir. Menurut (Grandin, 2009) tipe kognitif anak autis ada tiga, yakni (1) tipe visual; (2) tipe pemikir pola; (3) spesialis verbal. Ketiga tipe tersebut memiliki kelebihan dan kekurangan lainnya. Hal ini selaras dengan pernyataan (Sussman, 1999) yang menyatakan bahwa dalam pembelajaran, ASD atau anak dengan spektrun autisme lebih mudah memahami materi (lebih mudah dalam belajar) melalui media visual. Sehingga, guru dapat menggunakan media-media yang dapat mempermudahkan anak dalam belajar. Media tersebut dapat berupa benda konkret yang ada di sekitar anak atau juga dapat menggunakan gambar yang dapat dilihat dan dipahami oleh anak.

Berdasarkan tipe kognitif anak autis tersebut, dalam pembelajaran matematika guru dapat memulai pembelajaran kepada anak dengan menggunakan benda konkret. Dengan begitu, anak akan memiliki kesempatan dalam mengamati benda secara langsung, dapat memegang dan merasakan benda tersebut sehingga dapat mempermudah anak mengungkapkan benda yang mereka pegang. Hal ini selaras dengan yang diungkapkan oleh (Mustafa et al., 2016) siswa diberi kesempatan melakukan tindakan seperti mengamati atau melihat, merasakan dan mengungkapkan bentuk geometris pada objek yang diamati, atau siswa diajarkan untuk mengidentifikasi atau mengklasifikasikan objek sesuai dengan kemiripan karakter.

Melalui kesempatan siswa melakukan sendiri, maka akan memunculkan gesture atau macam gerak ekspresi yang ditimbulkan ketika melakukan kegiatan-kegiatan tersebut. Menurut (Hubbard et al., 2012). Kehadiran gesture saat berbicara telah terbukti dapat memengaruhi persepsi, pemahaman, pembelajaran, dan biasanya dapat mengembangkan anak. Menurut (StuddertKennedy, 1993) gesture juga bisa berupa gerakan tangan ataupun gerakan tubuh. Hal itu, selaras dengan pernyataan (Gibbs, 2006; Nunez, 2005) bahwa anak yang menggunakan gesture untuk mengungkapkan pengetahuan ataupun pemikiran harus terikat dengan tubuhnya. Oleh sebab itu, gesture merupakan ungkapan verbal yang dilakukan oleh tubuh, sehingga dapat membantu anak mengungkakan pemikiran atau pemahaman mereka. Gesture yang secara visual lebih terlihat ekspresif biasanya ialah wajah dan tangan.

Gesture visual dapat membantu anak dalam pembelajaran matematika. Hal tersebut didukung oleh pendapat (Cook, Friedman, Duggan, Cui, \& Popescu, 2017) yang mengungkapkan bahwa gesture membawa efek positif pada pembelajaran di beberapa domain, seperti matematika, sains, dan kosakata bahasa asing. Menurut (Mustafa et al., 2016) dalam pembelajaran matematika, sikap anak autis muncul secara alamiah dan memiliki perbedaan antara anak satu dengan anak lainnya. Hal tersebut didukung oleh (McNeill, 2000) bahwa dalam matematika yang menyertakan gesture ucapan dapat membentuk pikiran (kognitif). Oleh karena itu, gesture anak autis yang dimunculkan terdapat kesesuaian dan ketidaksesuaian sehingga dapat melihat kognitif anak autis tersebut. Melalui penggunaan media visual dan didukung gesture yang ditimbulkan anak ketika berhadapan dengan media visual akan membantu anak dalam pembelajaran matematika.

Pembelajaran matematika menggunakan media visual dapat juga digunakan pada materi penjumlahan bilangan bulat. Penjumlahan bilangan bulat merupakan materi yang tidak terlalu sulit bagi anak normal. Akan tetapi, penjumlahan materi bilangan bulat belum tentu mudah dipahami oleh anak autis. Oleh karena itu, untuk mempermudah pemahaman anak dalam materi penjumlahan dibutuhkan media visual yang dapat merangsang anak dalam membentuk kognitifnya. Berdasarkan penjelasan tersebut menunjukkan bahwa anak autis dalam berpikir memerlukan gambar ataupun media visual sebagai alat bantu dalam proses berpikirnya. Jadi, diperlukan waktu yang lebih untuk anak mengamati dan memainkan media visual atau gambar tersebut dikarenakan anak autis pada kognitifnya lebih ke visual (Tots, 2015). Oleh sebab itu, topik yang diambil peneliti dalam penelitian ini ialah bagaimana gesture yang ditunjukkan anak autis pada saat menyelesaikan soal matematika. Hal itu sejalan dengan tujuan peneliti, yaitu mendeskripsikan kesesuaian dan ketidaksesuaian gesture anak autis dalam belajar matematika.

\section{METODE}

Penelitian ini merupakan penelitian kualitatif dengan jenis penelitian studi kasus. Subjek pada penelitian ini ialah anak autis di Sekolah Luar Biasa Laboratorium Autis UM (SLB Lab Autis UM) yang terdapat empat anak autis dengan indikasi autistik yang berbeda-beda, sehingga diberi tugas untuk mengerjakan soal. Berdasarkan pemberian tugas mengerjakan soal tersebut untuk melihat gesture yang ditunjukkan peneliti memilih dua subjek dari empat subjek yang diberikan soal, yaitu dengan satu subjek memiliki kelebihan dalam matematika dan satu subjek lainnya kurang dalam matematika.

Sumber data yang digunakan dalam penelitian ini sumber data sekunder. sumber data sekunder merupakan sumber data yang diperoleh peneliti melalui dokumen yang berupa tulisan ataupun catatan yang berkaitan dengan gesture anak autis dalam menyelesaikan soal menjumlahkan bilangan bulat di SLB Lab Autis UM. Data tersebut juga dapat berupa foto-foto gesture anak dalam mengerjakan soal dan berasal dari video yang diambil untuk merekam gesture anak, agar dapat dijadikan bukti nyata atau bukti autentik dalam penelitian. 
Instrumen utama dalam penelitian ini ialah peneliti sendiri dikarenakan peneliti sendiri yang mengumpulkan data melalui rekaman ataupun observasi (Creswell, 2012). Alat yang digunakan peneliti untuk membantu penelitian ini ialah berupa; (1) kamera audio visual yang digunakan untuk merekam gesture yang muncul pada saat anak megerjakan soal; (2) lembar soal, soal yang disusun sesuai materi yang diajarkan (penjumlahan bilangan bulat) atau telah dipelajari oleh anak.

Penelitian ini menggunakan analisis data yang dibutuhkan. Adapun menurut (Kasiram, 2010), tujuan analisis data untuk mencari makna dibalik data melalui pengakuan subjek pelakunya. Peneliti akan menemukan data dari berbagai subjek pelakunya, untuk itu peneliti dapat mengumpulkan semua data tersebut dan mencari fakta dibalik data yang peneliti peroleh. Analisis tersebut dilakukan melalui empat proses, yaitu proses data collection, data reduction, data display dan yang terakhir proses conclusion drawing and verifying. Analisis pertama ialah dengan proses data collection, dimana peneliti harus mengumpulkan data penelitian secara keseluruhan melalui teknik observasi, wawancara, maupun dokumentasi. Setelah itu, peneliti melakukan proses data reduction, dimana peneliti menggolongkan keseluruhan paparan data sesuai dengan fokus penelitian yang diteliti. Kemudian, peneliti melakukan proses data display, dimana peneliti memaparkan seluruh data tersebut dalam bentuk kata (narasi), tabel, maupun gambar. Proses terakhir yakni conclusion drawing and verifying, dimana proses ini memiliki tujuan untuk menyimpulkan data yang telah peneliti peroleh dan digolongkan sesuai dengan fokus penelitian yang peneliti teliti.

\section{HASIL}

Berdasarkan hasil penelitian yang dilakukan diperoleh data bahwa anak dengan spektrum autisme (ASD) dalam menyelesaikan soal matematika penjumlahan bilangan bulat, menunjukkan berbagai gesture yang dilakukan anak autis. Hasil penelitian ini ialah berupa deskriptif yang berasal dari masing-masing subjek yang diteliti. Deskriptif analisis tersebut dapat diawali dari menganalisis video rekaman yang peneliti buat, selanjutnya memilih gesture seperti apa yang ditunjukkan oleh anak autis, selanjutnya membuat gambaran kesesuaian dan ketidaksesuaian gesture anak autis dalam menyelesaikan soal.

Pada kegiatan awal sebelum anak diberi soal, guru memberikan arahan seperti berapa dua hasil penjumlahan dari dua bilangan dengan menggunakan benda konkret seperti pensil yang ada di kelas. hal tersebut merupakan langkah awal guru dalam mengarahkan anak sebelum mengerjakan soal yang akan diberikan. Jika anak dirasa telah memahami arahan yang diberikan guru, maka anak dapat mengerjakan soal tersebut bersama dengan bimbingan guru. Kemudian peneliti menjelaskan/menggambarkan data dan analisis gesture yang ditunjukkan anak dalam menyelesaikan soal matematika melalui rekaman video. Analisis dilakukan pada dua anak autis yang dapat dikatakan cukup baik dalam matematika dan kurang dalam matematika.

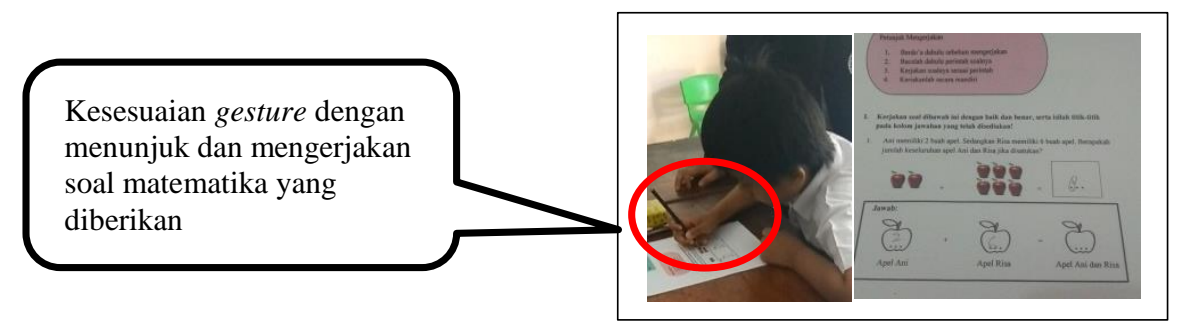

Gambar 1. Kesesuaian gesture dengan menunjuk dan mengerjakan soal matematika yang diberikan

Berdasarkan gambar 1, guru bersama dengan $\mathrm{R}$ mengidentifikasi soal berupa penjumlahan bilangan bulat yang divisualisasikan menjadi buah apel. Proses pertama R diminta guru memberikan identitas jumlah apel yang ada pada kolom pertama. Selanjutnya, guru meminta R memberikan identitas kembali pada jumlah apel yang ada pada kolom yang kedua. Respon $\mathrm{R}$ setelah mendengarkan arahan dari guru dan mengamati gambar yang ada pada lembar tugas yang diberikan, langsung memberikan gerakan menunjuk. Jumlah apel dari kedua kolom tersebut, memberikan respon dari $\mathrm{R}$ berupa gerakan menunjuk apel dan menghitung apel tersebut. Gesture yang ditunjukkan R dapat dikatakan baik, karena R menunjukkan penghitungan jumlah apel ada kolom 1 dan 2 secara benar dan melakukan gerakan dengan cocok. Selanjutnya, guru memberikan arahan kembali kepada R untuk menghitung semua apel yang ada pada kedua kolom tersebut. Akan tetapi, ketika R akan menuliskan jumlah apel keseluruhan, R tampak ragu. Oleh karena itu, guru memberikan arahan kembali kepada R agar mudah untuk menjumlahkan kedua bilangan tersebut. $\mathrm{R}$ yang diberikan arahan, mengikuti arahan guru dalam menghitung jumlah keseluruhan apel. Gerakan tangan dan anggukan kepala yang ditunjukkan $\mathrm{R}$ menunjukkan kesesuaian gerak. Sehingga, $\mathrm{R}$ dapat dikatakan baik dalam mereespon dan memberikan gerak dalam menyelesaikan soal pertama. 


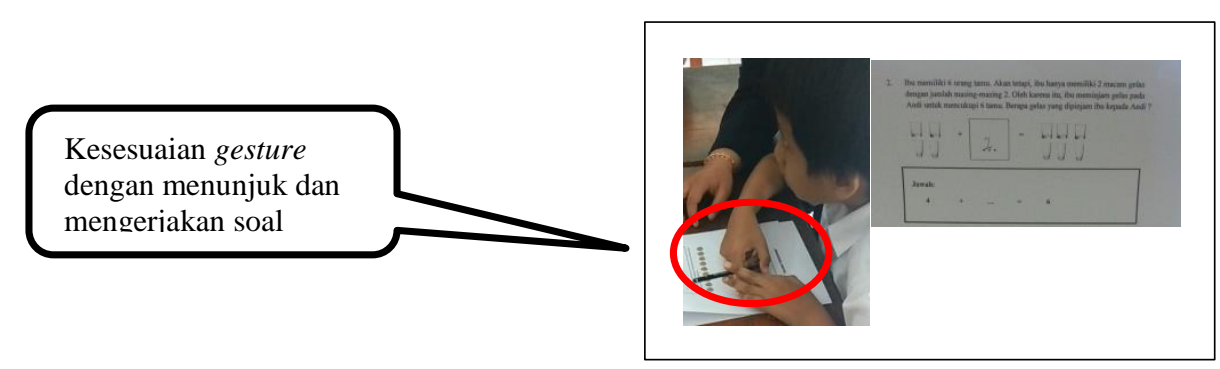

Gambar 2. Kesesuaian gesture dengan menunjuk dan mengerjakan soal

Berdasarkan gambar 2, guru bersama dengan $\mathrm{R}$ mengidentifikasi soal berupa penjumlahan bilangan bulat yang divisualisasikan menjadi gelas dengan penjumlahan bilangan yang hilang. Proses pertama R diminta guru menghitung jumlah gelas pada kolom pertama. Selanjutnya, guru meminta $\mathrm{R}$ menghitung jumlah gelas dari hasil penjumlahan bilangan yang hilang pada kolom yang ketiga. Respon R setelah mendengarkan arahan dari guru dan mengamati gambar yang ada pada lembar tugas yang diberikan, langsung memberikan gerakan menunjuk. Jumlah gelas dari kedua kolom tersebut, memberikan respon dari $\mathrm{R}$ berupa gerakan menunjuk gelasdan menghitung gelas tersebut. Gesture yang ditunjukkan R dapat dikatakan baik, karena R menunjukkan penghitungan jumlah gelas yang ada pada kolom 1 dan 3 secara benar dan melakukan gerakan dengan cocok. Selanjutnya, guru memberikan arahan kembali kepada $\mathrm{R}$ untuk menghitung berapa gelas yang perlu ditambahkan agar jumlah gelas keseluruhan adalah 6. Akan tetapi, ketika $\mathrm{R}$ akan menuliskan jumlah gelas yang diperlukan, $\mathrm{R}$ tampak ragu dan menunjukkan gerakan kepala menghadap guru beserta sorotan mata bertanya (tidak paham). Oleh karena itu, guru memberikan arahan kembali kepada $\mathrm{R}$ agar mudah untuk mengetahui jumlah gelas yang dibutuhkan. $\mathrm{R}$ yang diberikan arahan, mengikuti arahan guru dalam menghitung jumlah gelas yang diperlukan. Gerakan tangan dan gerakan kepala yang ditunjukkan $\mathrm{R}$ menunjukkan kesesuaian gerak dikarenakan dapat memahami maksud yang diberikan guru. Sehingga, R dapat dikatakan baik dalam merespon dan memberikan gerak dalam menyelesaikan soal kedua.

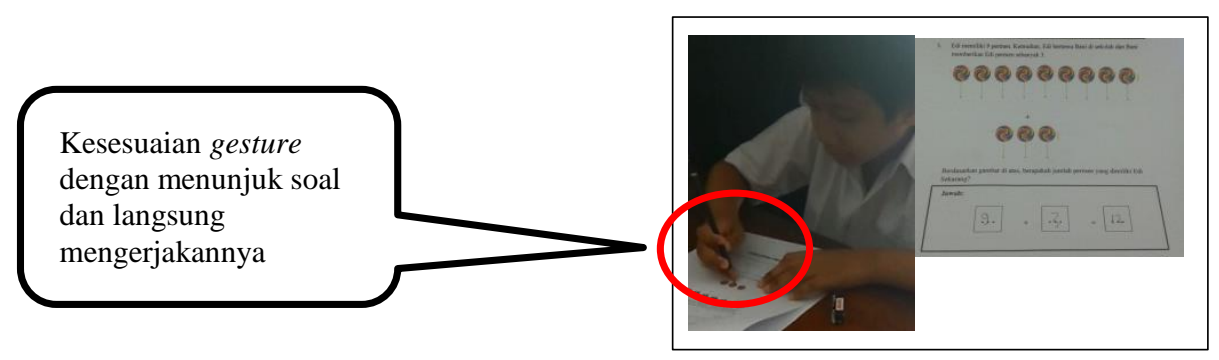

\section{Gambar 3. Kesesuaian gesture dengan menunjuk soal dan langsung mengerjakannya}

Berdasarkan gambar 3, guru bersama dengan $\mathrm{R}$ mengidentifikasi soal berupa penjumlahan bilangan bulat yang divisualisasikan menjadi permen. Proses pertama R diminta guru memberikan identitas jumlah awal permen Edi yang pada kolom pertama. Selanjutnya, guru meminta R memberikan identitas kembali pada jumlah permen Edi setelah diberi oleh Bani pada kolom yang kedua. Respon dari $\mathrm{R}$ setelah mendengarkan arahan dari guru dan mengamati gambar yang ada pada lembar tugas yang diberikan, tidak langsung mengisi identitas pada kolom melainkan menunjuk permen yang ada pada soal. Respon yang diberikan oleh $\mathrm{R}$ berupa gerakan menunjuk permen dan menghitung jumlah permen tersebut. Gesture yang ditunjukkan $\mathrm{R}$ dapat dikatakan kesesuaian gesture karena $\mathrm{R}$ menunjukkan permen dan langsung menghitungnya. Respon $\mathrm{R}$ tersebut yang berupa gerakan tangan dan kepala menunjukkan bahwa $\mathrm{R}$ menyukai objek tersebut sehingga $\mathrm{R}$ langsung menunjuk dan menghitung permen yang ada pada soal.

Berlawanan dari R, aktivitas lainnya yang ditampilkan dalam menyelesaikan soal matematika penjumlahan bilangan bulat. Berdasarkan gambar 4, guru bersama dengan I mengidentifikasi soal berupa penjumlahan bilangan bulat yang divisualisasikan menjadi buah apel. Proses pertama I diminta guru memberikan identitas jumlah apel yang ada pada kolom pertama. Selanjutnya, guru meminta I memberikan identitas kembali pada jumlah apel yang ada pada kolom yang kedua. Respon I setelah mendengarkan arahan dari guru dan mengamati gambar yang ada pada lembar tugas yang diberikan, langsung memberikan gerakan menunjuk. Jumlah apel dari kedua kolom tersebut, memberikan respon dari I berupa gerakan menunjuk apel dan menghitung apel tersebut. Gesture yang ditunjukkan I dapat dikatakan baik, karena I menunjukkan penghitungan jumlah apel ada kolom 1 dan 2 secara benar dan melakukan gerakan dengan cocok. Selanjutnya, guru memberikan arahan kembali kepada I 
untuk menghitung semua apel yang ada pada kedua kolom tersebut. Akan tetapi, ketika I akan menuliskan jumlah apel keseluruhan, I tampak ragu. Oleh karena itu, guru memberikan arahan kembali kepada I agar mudah untuk menjumlahkan kedua bilangan tersebut. I yang diberikan arahan, mengikuti arahan guru dalam menghitung jumlah keseluruhan apel. Gerakan tangan dan anggukan kepala yang ditunjukkan Imenunjukkan kesesuaian gerak. Sehingga, I dapat dikatakan baik dalam mereespon dan memberikan gerak dalam menyelesaikan soal pertama.

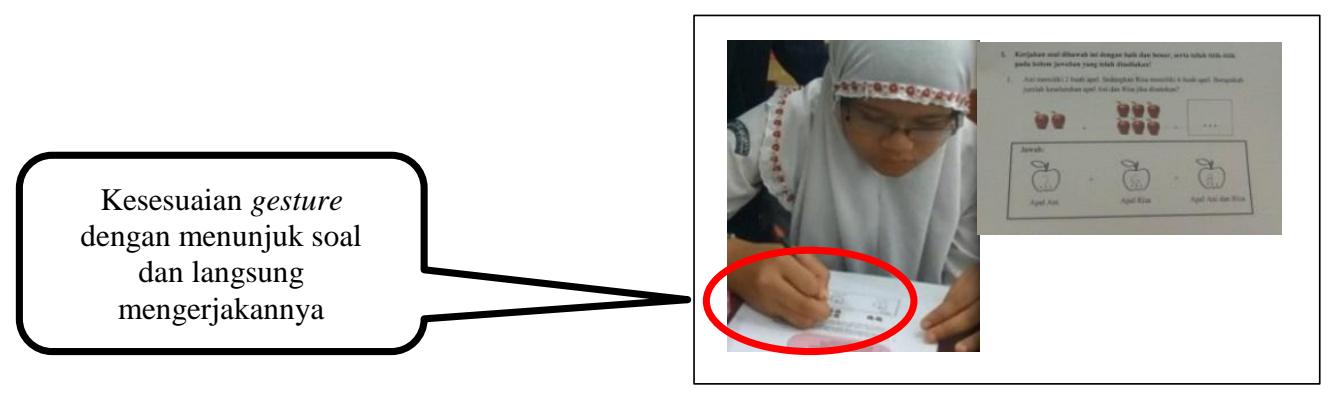

Gambar 4. Kesesuaian gesture dengan menunjuk soal dan langsung mengerjakannya

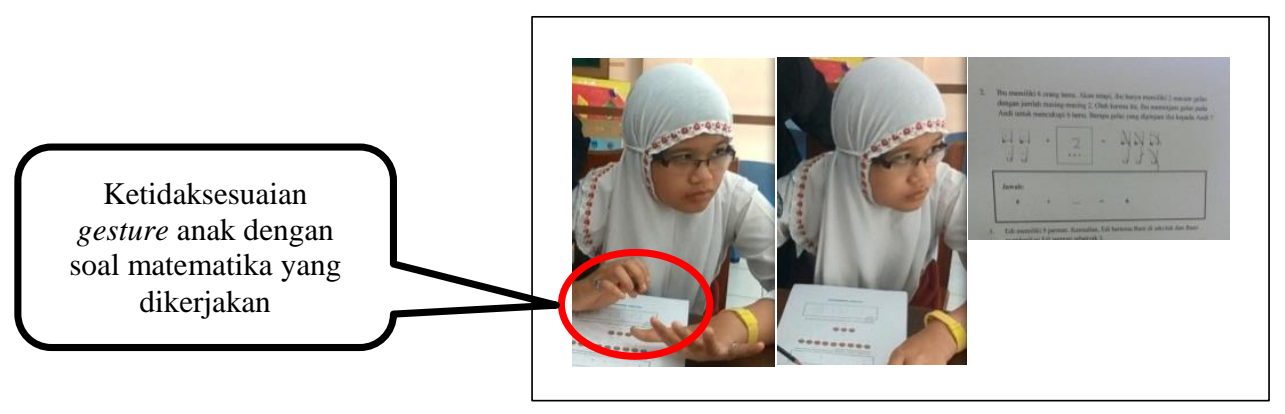

Gambar 5. Ketidaksesuaian gesture anak dengan soal matematika yang dikerjakan

Berdasarkan gambar 5, guru bersama dengan I mengidentifikasi soal berupa penjumlahan bilangan bulat yang divisualisasikan menjadi gelas dengan penjumlahan bilangan yang hilang. Proses pertama I diminta guru menghitung jumlah gelas pada kolom pertama. Selanjutnya, guru meminta I menghitung jumlah gelas dari hasil penjumlahan bilangan yang hilang pada kolom yang ketiga. Respon I setelah mendengarkan arahan dari guru dan mengamati gambar yang ada pada lembar tugas yang diberikan, langsung memberikan gerakan menunjuk. Jumlah gelas dari kedua kolom tersebut, memberikan respon dari I berupa gerakan menunjuk gelasdan menghitung gelas tersebut. Gesture yang ditunjukkan I dapat dikatakan baik, karena I menunjukkan penghitungan jumlah gelas yang ada pada kolom 1 dan 3 secara benar dan melakukan gerakan dengan cocok. Selanjutnya, guru memberikan arahan kembali kepada I untuk menghitung berapa gelas yang perlu ditambahkan agar jumlah gelas keseluruhan adalah 6. Akan tetapi, ketika I akan menuliskan jumlah gelas yang diperlukan, I tampak ragu dan menunjukkan gerakan kepala menghadap guru dengan gelengan kepala beserta sorotan mata bertanya (tidak paham). Oleh karena itu, guru memberikan arahan kembali kepada I agar mudah untuk mengetahui jumlah gelas yang dibutuhkan. I yang diberikan arahan, mengikuti arahan guru dalam menghitung jumlah gelas yang diperlukan dengan kurang baik. Gerakan tangan yang ditunjukkan untuk menghitung tidak sesuai dengan apa yang akan dihitung dan gerakan leher menoleh kearah guru dengan sorotan mata yang kurang sesuai. I menunjukkan ketidaksesuaian gerak dikarenakan kurang memahami maksud arahan yang diberikan guru. Sehingga, I dapat dikatakan kurang baik dalam merespon dan memberikan gerak ketidaksesuaian dalam menyelesaikan soal kedua.

Berdasarkan gambar 6, guru bersama dengan I mengidentifikasi soal berupa penjumlahan bilangan bulat yang divisualisasikan menjadi permen. Proses pertama I diminta guru memberikan identitas jumlah awal permen Edi yang pada kolom pertama. Selanjutnya, guru meminta I memberikan identitas kembali pada jumlah permen Edi setelah diberi oleh Bani pada kolom yang kedua. Respon dari I setelah mendengarkan arahan dari guru dan mengamati gambar yang ada pada lembar tugas yang diberikan, tidak langsung mengisi identitas pada kolom melainkan menunjuk permen yang ada pada soal berulang-ulang. Gesture yang ditunjukkan I dapat dikatakan ketidaksesuaian gesture, karena I menunjukkan permen bukan untuk menghitungnya melainkan menunjuk berulang-ulang. Respon I tersebut yang berupa gerakan tangan dan kepala menunjukkan bahwa I tidak 
memahami arahan yang guru berikan, sehingga guru memberi arahan kembali kepada I untuk memberikan identitas dan mengerjakan soal yang diberikan.

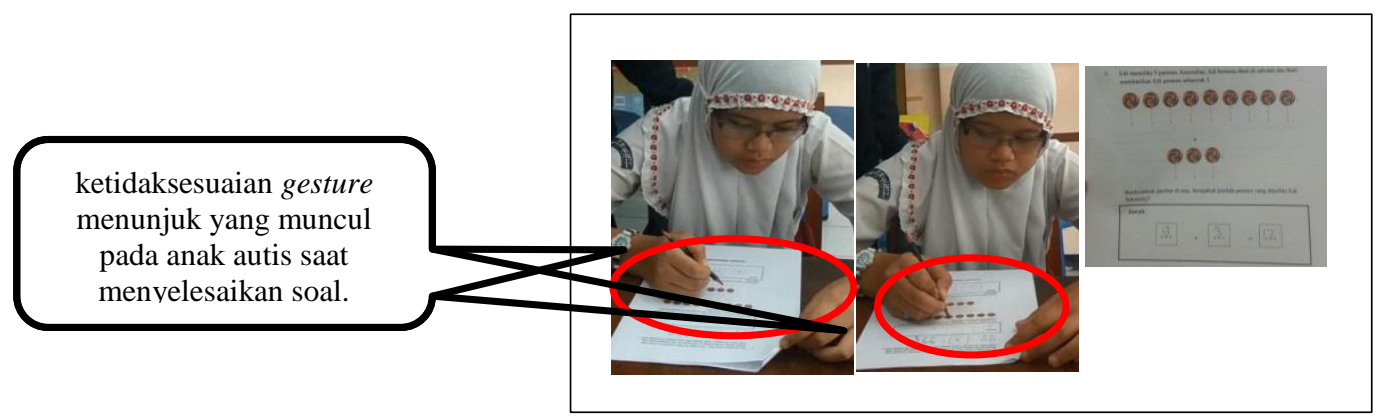

Gambar 6. Ketidaksesuaian gesture menunjuk yang muncul pada anak autis saat menyelesaikan soal

\section{PEMBAHASAN}

Pembelajaran matematika merupakan pembelajaran yang banyak tidak disukai oleh anak-anak regular di SD. Tidak hanya anak SD saja, melainkan anak autis yang bersekolah di SLB pun memiliki kecenderungan sulit memahami materi pembelajaran matematika. Anak autis merupakan anak yang memiliki gangguan sosial dan komunikasi. Hal tersebut didukung oleh pendapat (Iuculano et al., 2014) bahwa anak autis merupakan salah satu kelainan perkembangan pada saraf yang ditandai oleh definisi sosial dan komunikasi.

Anak autis dalam mengikuti pembelajaran di dalam kelas dapat digolongkan ketiga tipe kognitif atau cara berpikir. Hal ini selaras dengan pendapat (Grandin, 2009) mengungkapkan bahwa tipe kognitif anak autis ada tiga, yakni (1) tipe visual; (2) tipe pemikir pola; (3) spesialis verbal. Berdasarkan tipe kognitif tersebut, ada pula menurut (Sussman, 1999) yang mengungkapkan bahwa anak autis dalam pembelajaran lebih mudah memahami materi melalui media visual. Oleh karenanya, penggunaan media visual diperlukan untuk membantu anak autis dalam pembelajaran.

Penggunaan media pembelajaran untuk alat bantu peraga guru dalam menjelaskan dan memberi pemahaman kepada anak sangat diperlukan. Media yang digunakan merupakan media visual yang mudah dimengerti anak dan tidak menimbulkan kebingungan yang berlebih pada anak. Melalui penggunaan media, guru akan menjelaskan di depan kelas dengan berbicara. Bersamaan dengan penjelasan yang diberikan, guru akan memunculkan gesture saat memberikan penjelasan kepada guru. Hal tersebut didukung oleh pendapat (Hubbard et al., 2012) yang mengakatan bahwa kehadiran gesture saat berbicara telah terbukti dapat memengaruhi persepsi, pemahaman, pembelajaran dan mengembangkan anak. Oleh karenanya, dengan adanya gesture guru dapat lebih mudah memberikan pemahaman kepada anak autis, sehingga anak dapat lebih memahami materi pembelajaran.

Melalui penggunaan gesture, anak dapat mengungkapkan pengetahuan yang mereka miliki. Gesture dapat membawa efek positif untuk anak autis dalam pembelajaran. Hal tersebut dijelaskan oleh (Cook et al., 2017) bahwa gesture membawa efek positif dalam pembelajaran khususnya di beberapa domain, yakni seperti matematika, sains, dan kosakata bahasa asing. Oleh karenanya, gesture yang muncul pada anak dapat dikatakan baik atau sesuai maupun kurang baik atau terdapat ketidaksesuaian gesture. Munculnya gesture tersebut dapat dikatakan sesuai dan tidak sesuai karena dipengaruhi kognitifnya. Menurut (McNeill, 2000) dalam pembelajaran matematika, gesture ucapan dapat membentuk pikiran (kognitif) sehingga munculnya gesture yang sesuai dan tidak sesuai dapat dipengaruhi oleh kognitifnya.

\section{SIMPULAN}

Gesture yang dimunculkan oleh setiap anak autis dengan tingkat kognitif yang berbeda, juga akan berbeda pula hasilnya. Anak autis dengan tingkat kognitif sedang akan memunculkan kesesuaian gerkan lebih banyak dibandingkan dengan anak dengan kognitif dibawah. Gerakan ketidaksesuaian pun akan muncul pada anak autis yang memiliki kognitif cenderung rendah sehingga gerakan yang dimunculkan tidak sesuai. Oleh karena itu, guru diharapkan dapat lebih memahami gesture masing-masing anak autis agar guru dapat membuat anak lebih fokus dalam pembelajaran matematika.

\section{DAFTAR RUJUKAN}

Cook, S. W., Friedman, H. S., Duggan, K. A., Cui, J., \& Popescu, V. (2017). Hand Gesture and Mathematics Learning: Lessons From an Avatar. Cognitive Science, 41(2), 518-535. https://doi.org/10.1111/cogs.12344

Creswell, J. W. (2012). Research Desain Pendekatan Kualitatif, Kuantitatif, dan Mixed. Yogyakarta: Pustaka Belajar.

Gibbs, R. W., J. (2006). Embodiment and Cognitive Science. Cambridge: Cambridge University Press. 
Grandin, T. (2009). How Does Visual Thinking Work in the Mind of a Person with Autism? A Personal Account. Philosophical Transactions of the Royal Society B: Biological Sciences, 364(1522), 1437-1442. https://doi.org/10.1098/rstb.2008.0297

Hallmayer, J., Spiker, D., Lotspeich, L., McMahon, W. M., Petersen, P. B., Nicholas, P., ... Ciaranello, R. D. (1996). Male-toMale Transmission in Extended Pedigrees with Multiple Cases of Autism. American Journal of Medical Genetics Seminars in Medical Genetics, 67(1), 13-18. https://doi.org/10.1002/(SICI)1096-8628(19960216)67:1<13::AIDAJMG2>3.0.CO;2-T

Hubbard, A. L., Mcnealy, K., Scott-Van Zeeland, A. A., Callan, D. E., Bookheimer, S. Y., \& Dapretto, M. (2012). Altered Integration of Speech and Gesture in Children with Autism Spectrum Disorders. Brain and Behavior, 2(5), 606-619. https://doi.org/10.1002/brb3.81

Iuculano, T., Rosenberg-Lee, M., Supekar, K., Lynch, C. J., Khouzam, A., Phillips, J., ... Menon, V. (2014). Brain Organization Underlying Superior Mathematical Abilities in Children with Autism. Biological Psychiatry, 75(3), 223230. https://doi.org/10.1016/j.biopsych.2013.06.018

Kasiram, M. (2010). Metodologi Penelitian Kualitatif - Kuantitatif. Malang: UIN Maliki Press.

McNeill, D. (1992). Hand and Mind: What Gestures Reveal about Thought. Haskins Laboratories Status Report on Speech Research, (1992), 149-153. https://doi.org/10.1177/002383099403700208

McNeill, D. (2000). Language and Gesture. Chicago, IL: The University of Chicago Press.

Mundy, P., \& Markus, J. (1997). On the Nature of Communication and Language Impairment in Autism. Mental Retardation and Developmental Disabilities Research Reviews, 3(4), 343-349.

Mustafa, S., Nusantara, T., Subanji, S., \& Irawati, S. (2016). Mathematical Thinking Process of Autistic Students in Terms of Representational Gesture. International Education Studies, 9(6), 93. https://doi.org/10.5539/ies.v9n6p93

R. nunez. (2005). Do Real Numbers Really Move? Language, Thinking, and Gesture: The Embodied Cognitive Foundations of Mathematics.

Swillen, A., Hellemans, H., Steyaert, J., \& Fryns, J. P. (1996). Autism and Genetics: High Incidence of Specific Genetic Syndromes in 21 Autistic Adolescents and Adults Living in Two Residential Homes in Belgium. American Journal of Medical Genetics, 67(3), 315-316. https://doi.org/10.1002/(SICI)1096-8628(19960531)67:3<315::AIDAJMG9>3.0.CO;2-L

Szatmari, P., Jones, M. B., Holden, J., Bryson, S., Mahoney, W., Tuff, L., ... Hoult, L. (1996). High Phenotypic Correlations among Siblings with Autism and Pervasive Developmental Disorders. American Journal of Medical Genetics - Seminars in Medical Genetics, 67(4), 354-360. https://doi.org/10.1002/(SICI)1096-8628(19960726)67:4<354::AID-

AJMG7>3.0.CO;2-M 